Volume 2, Nomor 1, Tahun 2020 Hal 265 - 281

\title{
Mempersiapkan Blended Learning Melalui Pelatihan Pembuatan E-Modul untuk Guru Madrasah Tsanawiyah YAPPI Mulusan
}

\author{
N Masta ${ }^{1}$, Septina Severina Lumbantobing ${ }^{2}$, Taat Guswantoro ${ }^{3}$, Faradiba ${ }^{4}$, Nya \\ Daniaty Malau ${ }^{5}$
}

1,2,3,4,5 Universitas Kristen Indonesia, Jakarta, Indonesia

Email: 1ngia.masta@uki.ac.id; 2septina.lumbantobing@uki.ac.id;

3taat.guswantoro@uki.ac.id, ${ }^{4}$ faradiba@uki.ac.id, ${ }^{3}$ nya.malau@uki.ac.id

\begin{abstract}
Abstrak
Penggunaan e-modul dalam pendekatan blended learning mutlak diperlukan agar siswa dapat mengakses sumber belajar sesuai kurikulum. Namun eksistensi emodul masih belum luas dikenal pada kalangan guru. Untuk itu, dilakukan pelatihan pembuatan e-modul menggunakan software SIGIL kepada guru-guru di MTs YAPPI Mulusan, dalam rangka Pengabdian Kepada Masyarakat (PKM) oleh Program Studi Pendidikan Fisika FKIP UKI. Sebagai evaluasi digunakan angket kepuasan partisipan terhadap pelatihan. Adapun temuan hasil survey diantaranya: 1) Seluruh partisipan sangat setuju bahwa pelatihan pembuatan e-modul bermanfaat dalam pembelajaran; 2) Sebanyak $87,5 \%$ partisipan setuju bahwa software SIGIL dapat digunakan secara sederhana dalam membuat e-modul, sementara terdapat $50 \%$ partisipan sangat setuju bahwa software SIGIL bersifat kebaruan; 3) Sebanyak $71,9 \%$ partisipan puas atas kebermanfaatan e-modul yang dihasilkan dari pelatihan; dan 4) Sebanyak 95,6\% partisipan puas terhadap instruktur. Demikian PKM ini telah dilaksanakan dengan baik, diharapkan para guru mampu mengembangkan e-modul dalam mempersiapkan blended learning.
\end{abstract}

Kata Kunci: Guru; E-Modul; SIGIL; Blended Learning

\begin{abstract}
The utilization of e-module is infallible be required in blended learning approach. Nevertheless, the existence of e-modul has not been wide known among teachers. Therefore training on e-module design through SIGIL software for teachers in MTs YAPPI Mulusan been done, as community service (PKM) activity by Physics Education Study Programme, FKIP UKI. The survey questionnaire used to evaluated the participant satisfaction. The surveys finding including: 1) All participant strongly agree that the training was beneficial in learning activity; 2) As many $87,5 \%$ participant agree that SIGIL as uncomplicated software to design e-module, while only 50\% participants strongly agree that SIGIL as up to date software; 3) As many $72,9 \%$ participant satisfy with the usability of e-modul produced; and 4) As many $95,6 \%$ participant satisfy with the trainer. Hence, this community service implemented quite well, likewise the expectation of e-module development be concerning to the blended learning preparation.
\end{abstract}

Keywords:Teacher, E-Module, SIGIL, Blended Learning

\section{PENDAHULUAN}

Kejayaan minyak dan kayu telah

usai, demikian pula dengan kejayaan sumber daya alam lainnya, oleh sebab itu untuk mempersiapkan masa depan yang perlu dibangun 
Volume 2, Nomor 1, Tahun 2020 Hal 265 - 281

adalah sumber daya manusianya.

Pondasi pembangunan sumber daya manusia yang berkualitas adalah sumber daya manusia yang menguasai ilmu pengetahuan dan teknologi. Penggunaan teknologi untuk pembelajaran sedang menjadi tren perkembangan riset pendidikan dalam berbagai bidang dan di berbagai belahan dunia saat $\mathrm{nni}^{123}$. Persebaran penggunaan komputer dan internet memicu pengembangan software yang cepat, penggunaan tablet computer, dan perkembangan teknologi pembaca buku digital sama halnya dengan konversi buku konvensional dengan e-book 1 . Perangkat pembelajaran juga kini berkembang dengan cepat, sejak dikembangkannya kindle oleh Amazon dan Nook oleh produk Barnes \& Noble ${ }^{4}$.

Namun perkembangan yang begitu cepat ini belum beriringan dengan teknologi pembelajaran di Indonesia. Hal ini menimbulkan kesenjangan pada media dan strategi pembelajaran yang biasa digunakan dengan gaya hidup siswa. Kesenjangan penggunaan teknologi pembelajaran disebabkan oleh kurangnya pengetahuan guru dalam penguasaan teknologi, bahkan dari sejak masih mahasiswa calon guru 5 . Fenomena ini mengakibatkan kurang maksimalnya pelibatan teknologi digital dalam pembelajaran. Semestinya pembelajaran disesuaikan dengan kehidupan siswa, salah satunya dengan media pembelajaran yang digunakan. Dengan demikian media pembelajaran yang digunakan mesti diarahkan pada dunia digital, yaitu pembelajaran berbasis digital.

Kemajuan teknologi digital sudah semestinya dimanfaatkan secara maksilmal untuk pembelajaran. Pembelajaran berbasis digital saat ini dilakukan melalui dua cara, yaitu online learning dan blended learning. Blended learning merupakan suatu pendekatan pembelajaran yang memadukan pembelajaran online dan pembelajaran offline, sehingga masih melibatkan tatap muka dalam prosesnya. Dalam pendekatan ini ada banyak keuntungan yang dapat diperoleh oleh pembelajar (siswa), diantaranya memperoleh kebermanfaatan teknologi 
Volume 2, Nomor 1, Tahun 2020 Hal 265 - 281

komunikasi, memperoleh waktu yang

lebih lama dalam mengeksplorasi dan mengkonstruksi pengetahuan, dan memperoleh kebermanfaatan dari pembelajaran offline yang melibatkan interaksi secara langsung, misalnya praktikum, tanya jawab, diskusi dan presentasi secara langsung. Perpaduan inilah yang membuat pendekatan Blended Learning lebih banyak dipilih dalam pelibatan teknologi kedalam pembelajaran. Keberadaan blended learning telah menjadi hal yang biasa dikembangkan di beberapa negara maju, namun belum di Indonesia. Untuk itu diperlukan suatu upaya untuk mengejar ketertinggalan ini.

Pada penelitian ini, modul konvensional didefinisikan sebagai modul yang dicetak. Sementara emodul adalah versi digital dari sebuah modul konvensional. Lebih luas, sebuah e-modul berisi paduan materi/ konten yang terdapat dalam modul konvensional dengan teknologi mobile yang interaktif dengan tujuan agar siswa memiliki pemahaman yang lebih komprehensif dari yang diperolehnya di buku konvensional ${ }^{6}$.
E-Modul digunakan untuk melengkapi lingkungan digital, yang dapat dilihat dan diakses oleh setiap perangkat yang sesuai, misalnya komputer atau perangkat pembaca ebook $^{5}$. E-book adalah bentuk elektronik dari buku konvensional, sebagaimana e-modul. Perbedaan emodul dan e-book sama dengan perbedaan modul dan buku. E-modul dapat dibuat dengan melakukan konversi dari bentuk doc, txt, pdf ke dalam format $\mathrm{EPUB}^{4}$ sehingga dapat dibaca dengan resolusi yang menyesuaikan layar elektronik selain komputer, misalnya telepon genggam, PDA dan komputer tablet ${ }^{5}$. E-modul didesain agar dapat diunduh dari website dengan mudahdan digunakan dimana saja dan oleh kalangan mana pun selama memiliki perangkat yang sesuai ${ }^{74}$. Fasilitas yang dimiliki oleh e-modul saat ini sudah sama dengan buku konvensional, diantaranya dapat di highlight, navigator, focusing, dan bookmark. Penggunaan e-modul salah satunya banyak dilakukan dalam pendekatan fliiped classroom, yaitu sebuah pendekatan pembelajaran yang memberlakukan 
Volume 2, Nomor 1, Tahun 2020 Hal 265 - 281

pemahaman materi dasar di luar kelas sedangnakn enugasan, praktikum, tes dan diskusi dilakukan di dalam kelas. E-book berisi tentang materi pembelajaran di luar dan di dalam kelas, menyediakan fasilitas catatan dan berbagi catatan pada sesama siswa dan kepada guru ${ }^{1,6}$. Lebih lanjut, e-modulyang interaktif juga dapat menyediakan fasilitas monitoring; guru dapat mengetahui keadaan sebelum dan setelah pembelajaran pada setiap siswa, merekam seluruh catatan yang dibuat siswa, melakukan asesmen terhadap pembelajaran ${ }^{1,6}$.

Perkembangan e-modul cukup pesat dalam pendidikan internasional $^{7}$, perannya tidak hanya sebagai sumber bahan ajar, melainkan dapat dijadikan sebagai projek pembelajaran bagi siswa sekolah dasar dalam mempelajari "Tumbuhan dan Lingkungan"1. Dimasa mendatang, bentuk digital dari sebuah literasi cetak diprediksi dapat menjadi kanibal bagi literasi cetak tersebut, demikian pula emodul terhadap sebuah modul konvensional (Levy, s ,2000) ${ }^{4}$. Dilain pihak, pebelajar saat ini telah lebih banyak menggunakan literasi digital dibandingkan literasi konvensional, sebanyak $66,7 \%$ mahasiswa tingkat akhir menggunakan e-book, jumlah ini jauh lebih tinggi dibandingkan mahasiswa pada tingkat yang lebih rendah. Hal ini disebabkan mahasiswa tingkat akhir memerlukan referensi buku lebih banyak dalam penyelesaian tugas pembelajarannya 5.

E-book memegang peranan penting dalam blended learning, pendekatan ini dapat berhasil dilakukan apabila telah tersedia emodul yang telah didesain agar peserta didik dapat mencapai tujuan pembelajaran yang ditetapkan dalam kurikulum. Sebagaimana Hwang, $\mathrm{H}, \mathrm{J}$ menemukan bahwa pada pelaksanaan flipped learning, keberadaan e-modul menjembatani aktivitas di dalam dan di luar kelas dengan menyediakan materi pembelajaran yang interaktif dan dapat diakses oleh perangkat mobile'.

\section{Kelebihan dan kelemahan penggunaan E-Modul}


Volume 2, Nomor 1, Tahun 2020 Hal 265 - 281

Berdasarkan dampaknya terhadap lingkungan

Sebuah studi LCA (life Cycle Assesment) 7 menemukan bahwa berdasarkan dampak terhadap lingkungan, literasi dalam bentuk elektronik memiliki empat keunggulan dibandingkan literasi konvensional, yaitu: 1) ruang penyimpanan lebih sedikit daripada buku print; 2) Emodul meniadakan biaya transportasi personal; 3) E-readers, yaitu perangkat keras maupun lunak yang digunakan untuk membaca e-modul, memiliki sistem yang lebih terpadu dan tidak memerlukan banyak material daripada Buku konvensional; 4) Penggunakan listrik pada E-reader memiliki dampak yang lebih kecil daripada buku konvensional; 5) Sebagian file e-modul bahkan memiliki fasilitas dapat terurai sendirinya (self decompossed) ${ }^{4}$.

Berdasarkan pengayaan / fitur multimedia

E-modul berisi materi yang ada di modul konvensional, namun dilengkapi dangan teknologi digital. Sehingga isi dalam e-modul seharusnya lebih kaya dari buku konvensional, yaitu tersedianya fasilitas multimedia diantaranya video tutorial, simulasi, dan rekaman suara. Fasilitas ini tentunya sangat membantu siswa dalam mengkonstruksi dan mengorganisir pengetahuannya ${ }^{5}$. Penggunaan Ebook yang interaktif menurut Hwang dapat membantu meningkatkan keberhasilan belajar siswa tanpa seberapa pun tingkat keefektifan belajarnya, bahkan lebih lanjut dapat meningkatkan minat baca pada diri siswa ${ }^{1}$. Manfaat penggunaan e-book dapat dioptimalkan melalui fitur interaksi yang disediakan, sebagaimana Hwang (2016) menggunakan pembuatan ebook tanaman sekolah sebagai projek pembelajaran. Hwang menemukan bahwa project pembuatan ebook yang diintegrasikan dengan umpan balik rekan sejawat dapat meningkatkan keberhasilan belajar, luaran buku yang lebih baik, dan kecenderungan berfikir inovatif yang lebih tinggi jika dibandingkan dengan siswa yang hanya diminta membuat ebook biasa1.

Berdasarkan perbandingannya dengan buku konvensional 
Volume 2, Nomor 1, Tahun 2020 Hal 265 - 281

Melalui penggunaan e-modul, proses membaca e-modul dapat dianalisis dan diinterpretasikan, namun proses membaca buku konvensional lebih sulit. Siswa yang lebih menyukai e-book memiliki kemampuan literasi lebih tinggi daripada siswa yang lebih memlilih buku konvensional ${ }^{6}$. Kemampuan literasi yang lebih tinggi disebabkan karena e-book memiliki fitur yang menyediakan stimulus multisensoris (visual, kinestetis, dan akustik) sehinga meningkatkan konsentrasi membaca pada siswa, bahkan pada siswa di tingkat sekolah dasar ${ }^{19}$.

Seagaimana data digital biasanya, ebook mudah ditransfer dan dikompresi ke dalam satuan data dan ukuran rendah ${ }^{4}$

Keterbatasan e-modul

Namun keseluruhan kelebihan dari e-modul hanya akan dapat dicapai apabila memiliki dua prinsip berikut, yaitu komprehensif dan interaktif. Komprehensif artinya menyediakan materi / konten yang sangat datail, lengkap, padat. Sedangkan prinsip interaktif dapat dicapai melalui: 1) menyediakan fasilitas video, animasi, simulasi pembelajran $^{6}$; 2) menyediakan fasulitas membuat catatan berupa pertanyaan yang ditemui siswa tentang konsep atau fenomena yang tidak ia pahami6; 3) menyediakan fasilitas berbagi catatan, pertanyaan, atau diskusi online baik antar rekan sebaya, maupun dengan guru6; 4) menyediakan fasilitas untuk Game Based Learning (minimal menyediakan platform kuis online) ${ }^{8}$; 6) menyediakan gambar/ ilustrasi/ skema yang sesuai dengan karakteristik peserta didik ${ }^{9}$. Adapun beberapa kelemahan dalam penggunaan e-modul diantaranya: 1) Tidak sesuai untuk peserta didik dengan gaya belajar kinestetik ${ }^{10}$; 2) E-modul tidak kondusif untuk dibaca dalam jangka waktu yang lama. ${ }^{7}$; 3) Short Chunks, yaitu materi yang dipaparkan dalam bentuk singkat ${ }^{7}$.

\section{Sigil dan penelitian penggunaan SIGIL}

Sigil merupakan sebuah software tak berbayar yang digunakan untuk menghasilkan file dengan epub. Epub adalah singkatan dari publikasi elektronik, dimana jenis eksistansi file ini populer digunakan untuk 
Volume 2, Nomor 1, Tahun 2020 Hal 265 - 281

menyimpan eBook dan jenis konten lainnya. File epub dapat menyimpan kata, gambar, stylesheet, font, detail metadata, dan daftar isi. Mereka dianggap tata letak agnostik, yang berarti bahwa ukuran layar tidak mempengaruhi format epub file dapat menampilkan konten pada layar sekecil 3,5". Ini dan fakta itu adalah standar yang tersedia secara gratis mengapa mayoritas eReader mendukung file epub. Format inilah yang membuat sebuah modul dapat ditampilkan menyesuaikan dengan layar gadget yang digunakan, sehingga tidak perlu dilakukan proses zoom yang terlalu banyak, sebagaimana pdf dan word.

\section{Pengabdian Kepada Masyarakat} Program Studi Pendidikan Fisika FKIP UKI di MTs YAPPI Mulusan

$\begin{array}{lr}\text { Pengabdian } & \begin{array}{r}\text { kepada } \\ \text { dilaksanakan }\end{array} \\ \text { berdasarkan Undang-Undang Nomor } \\ 20 \text { Tahun } 2003 \text { tentang } & \text { Sistem } \\ \text { Pendidikan Nasional dan Undang- } \\ \text { Undang Nomor } 12 \text { Tahun } 2012 \\ \text { tentang Pendidikan } \\ \text { Pengabdian kepada Masyarakat } \\ \text { bertujuan untuk mengamalkan dan }\end{array}$

membudayakan ilmu pengetahuan dan teknologi dalam rangka memajukan kesejahteraan umum dan mencerdaskan kehidupan bangsa. Pengabdian kepada Masyarakat dapat dilakukan dalam berbagai bntuk sesuai dengan otonomi keilmuan sivitas akademika serta kondisi sosial budaya masyarakat. Salah satu permasalahan yang diangkat dalam pengabdian kepada masyarakat ini adalah terjadinya gagap teknologi dalam pendidikan. Oleh sebab itu melalui pengunaan teknologi digital dalam menyajikan materi pembelajaran melalui e-modul, diharapkan dapat meningkatkan kualitas pembelajaran, terutama bagi peserta didik.

Sebagai salah satu upaya adalah dengan melakukan konversi dari modul pembelajaran ke format emodul, Hasil dari pengabdian kepada masyarakat digunakan sebagai proses pengembangan ilmu pengetahuan dan teknologi, pengayaan sumber belajar, dan/atau untuk pembelajaran dan pematangan sivitas akademika. Maka dalam hal ini, program studi Pendidikan fisika 
Volume 2, Nomor 1, Tahun 2020 Hal 265 - 281

FKIP UKI melakukan dan ketimpangan pelaksanaan pendidikan. tujuan penelitian adalah melakukan pelatihan pembuatan e-

modul kepada guru-guru MTs YAPPI Mulusan, Gunung Kidul, Yogyakarta dan mengetahui respon dari partisipan terhadap pelatihan.

\section{METODE PELAKSANAAN}

Kegiatan pelatihan pembuatan e-modul dalam rangka pengabdian kepada masyarakat Program Studi Pendidikan Fisika FKIP Universitas Kristen Indonesia dilaksanakan pada tanggak 17-19 Juli 2019 di MTs Yappi Mulusan, Gunung Kidul, Yogyakarta. Kegiatan ini dilaksanakan berdasarkan Surat Tugas oleh Dekan
Fakultas Keguruan dan IImu Pendidikan Universitas Kristen Indonesia No. 195/F1.D/ST/2019. Pelaksanaan pengabdian kepada masyarakat ini dilakukan atas kerjasama dengan STIKES Bethesda. Pelakasanaan e-modul merupakan salah satu bagian dari pelaksanaan kegiatan ini, yang dilakukan dalam tiga tahap (Tabel 1).

Tabel 1 Tahapan Pelaksanaan Pelatihan E-Modul

\begin{tabular}{|c|c|}
\hline $\begin{array}{c}\text { Metode } \\
\text { Pelaksanaan }\end{array}$ & Uraian kegiatan \\
\hline 1. Persiapan & $\begin{array}{l}\text { a. Instalasi software SIGIL ke desktop } \\
\text { b. Modul konvensional dalam format .doc atau .docx } \\
\text { c. (1 topik/ } 1 \text { bab pembelajaran) } \\
\text { d. Presentasi singkat mengenai e-modul, HTML, epub, } \\
\text { SIGIL, dan e-reader }\end{array}$ \\
\hline 2. Pelatihan & $\begin{array}{l}\text { a. Mengkonversi file .doc dan .docs ke HTML } \\
\text { b. Membuka, menyimpan, dan menutup Sigil dari } \\
\text { komputernya. } \\
\text { c. Mengganti kata (replace) pada E- modul } \\
\text { d. Menyisipkan Gambar dan Video dalam E-Modul. } \\
\text { e. Menyisipkan Tabel dan Rumus dalam E-Modul } \\
\text { f. Membelah halaman HTML } \\
\text { g. Memasang Cover } \\
\text { h. Mengedit Daftar Isi } \\
\text { i. Membuka E-Modul dari desktop dan android }\end{array}$ \\
\hline 3. Evaluasi & $\begin{array}{l}\text { Survei kepuasan partisipan terhadap pelaksanaan pelatihan } \\
\text {. }\end{array}$ \\
\hline
\end{tabular}


Peserta adalah guru MTs YAPPI Mulusan sebanyak 8 (delapan) orang. Instruktur dalam kegiatan ini adalah dosen- dosen program studi pendidikan fisika fakultas kerguruan dan ilmu pendidikan universitas kristen indonesia, Jakarta. Kepuasan peserta terhadap pelatihan dievaluasi melalui metode survei. Dengan setiap pertanyaan berupa sebuah pernyataa nyang kemudian diberikan 5 (lima) alternatif jawaban, yaitu sangat setuju (SS), setuju (S), tidak tahu (R), tidak setuju (TS), dan sangat tidak setuju (STS) dengan pernyataan yang diberikan. Penskoran kemudian dilakukan menggunakan skala Likert. Respon yang dievaluasi dalam pelatihan ini adalah 1) Kepuasan partisipan terhadap kebermanfaatan pelatihan terhadap pembelajaran; 2) Kepuasan partisipan terhadap software SIGIL dalam membuat emodul; 3) Kepuasan partisipan terhadap e-modul yang dihasilkan dari pelatihan; dan 4) Kepuasan partisipan pada instruktur kegiatan. Selanjutnya umpan balik dari partisipan ditabulasi dan dianalisis sehingga dapat digunakan untuk pelaksanaan kegiatan pelatihan berikutnya.

\section{HASIL DAN PEMBAHASAN}

Berdasarkan tanya jawab singkat antara instruktur dan partisipan diperoleh gambaran umum bahwa guru-guru belum terbiasa dengan keberadaan e-book. Hal ini disebebkan karena guru-guru belum memiliki pengetahuan yang memadai tentang E-book atau buku elektronik Hal ini dapat dikarenakan pada saat menjadi mahsiswa calon guru tidak dibekali dengan pengetahuan dan keterampilan digital yang memadai. Hal ini serupa dengan penelitan Yalman, et al pada 543 mahasiswa calon guru di sebuah Universitas di Turki dari 4 tingkatan dan 7 departemen, diperoleh bahwa sebanyak 25,41\% mahasiswa tidak memiliki pemahaman yanga benar tentang definisi e-book; dan sebanyak $39,23 \%$ mahasiswa tidak mengetahui bagaimana membeli ebook; bahkan sebanyak $71,27 \%$ mahasiswa tidak mengetahui format e-book, 15,47\% mengira bahwa format e-book adalah pdf; dan 
Volume 2, Nomor 1, Tahun 2020 Hal 265 - 281

$10,50 \%$ mengira bahwa format ebook adalah doc, xls dan ppt.

\section{Kepuasan partisipan terhadap kebermanfaatan pelatihan terhadap pembelajaran}

Salah satu indikator dalam menentukan keberhasilan pelatihan dalam pembelajaran adalah persepsi partisipan bahwa kegiatan pelatihan bermanfaat dalam proses pembelajaran yang akan diselenggarakan oleh setiap partisipan setelah pelatihan selesai dilaksanakan (Gambar 1). Dari angket survei yang disebar, diperoleh bahwa seluruh partisipan sangat setuju bahwa kegiatan pelatihan ini sangat bermanfaat dalam pembelajaran. Hasil ini dapat dipengaruhi karena materi pelatihan yang disampaikan membuka wawasan baru terhadap para partisipan yang merupakan guru untuk dapat mempersiapkan bahan ajarnya berupa modul pembelajaran.

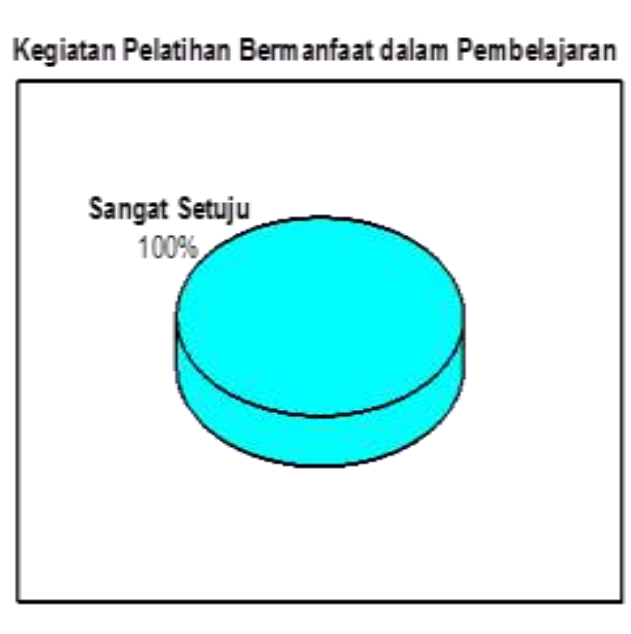

\section{Gambar 1 Diagram kepuasan partisipan terhadap kebermanfaatan pelatihan terhadap pembelajaran}

Mempersiapkan modul pembelajaran sangat penting agar peserta didik dapat mengikuti pembelajaran dan dapat secara efektif mencapai tujuan pembelajaran sebagaimana yang telah disusun melalui kurikulum. Modul memberikan penuntun yang telah sesuai dengan tingkat pemahaman dan bahasa yang digunakan oleh peserta didik dan menuntun peserta didik dalam menentukan bahanbahan atau topik yang harus dipelajari. Dengan ketersediaan modul, peserta didik tidak memerlukan waktu yang lebih banyak 
Volume 2, Nomor 1, Tahun 2020 Hal 265 - 281

dalam menentukan topik-topik yang akan dipelajarinya.

Lebih lanjut, dari hasil survey diperoleh bahwa semua partisipan setuju bahwa pelatihan ini bermanfaat untuk pembelajaran. Hal ini sejalan dengan Hwang (2015) bahwa penerapan teknologi mobile dalam pembelajaran oleh guru dirasakan akan meningkatkan kualitas pembelajaran ${ }^{2}$. Hal ini dapat disebabkan karena dalam menyusun suatu bahan ajar perangkat pembelajaran semakun lengkap, dan sumber belajar yang dimiliki siswa menjadi lebih lengkap pula. Konversi modul konvensional menjadi e-modul juga menyesuaikan dengan gaya komunikasi peserta didik saat ini, sehingga siswa dapat lebih leluasa dalam mengakses sumber belajarnya. Dalam pembuatan emodul guru juga dikenalkan dengan publikasi buku elektronik (e-book) dan dapat mengkomersilkan hasil karyanya.

\section{Kepuasan partisipan terhadap Software SIGIL versi 0.9.14.0 yang digunakan dalam pembuatan E-Modul}

Software SIGIL versi 0.9.14.0 merupakan sebuah software yang dapat digunakan untuk mengkonversi file dengan format .html menjadi .epub. file dengan eksistensi .html merupakan file elektronik yang digunakan untuk pembacaan tampilan dalam web. Dalam pelatihan ini digunakan file .doc dan .docx untuk selanjutnya disimpan dalam bentukhtml dengan cara melakukan save as dengan format web page. Sebelum melakukan penyimpanan dalam bentuk web page, dilakukan pemformatan dalam teks word. Beberapa pemformatan yang dilakukan dari teks word diantaranya pemformatan title, subtitle, heading, dan teks biasa, pemformatan tabel, gambar, dan persamaan. Untuk pemformatan persamaan dalam bentuk equation dilakukan dengan mengkonversi persamaan kedalam format gambar, misalnya jpeg atau png. 
Volume 2, Nomor 1, Tahun 2020 Hal 265 - 281

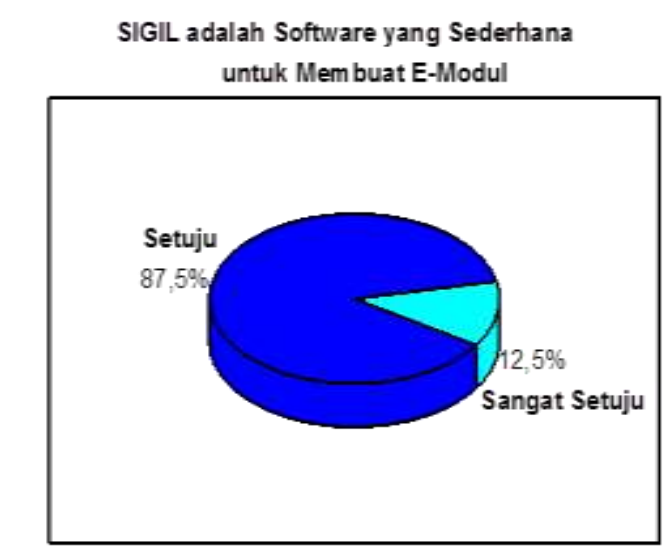

Gambar 2 Diagram kepuasan partisipan terhadap kemudahan (kesederhanaan) software SIGIL dalam pembuatan e-modul

Kepuasan partisipan terhadap software SIGIL dalam pelatihan menunjukkan hanya $12,5 \%$ partisipan yang sangat setuju bahwa SIGI dapat digunakan dengan sederhana (Gambar 2). Hal ini menggambarkan bahwa penggunaan SIGIL dalam memproduksi e-modul menemukan kesulitan dalam pelatihan, yaitu dalam menggunakan software ini masih diperlukan sedikit modifikasi dalam koding yang dipakai Software SIGIL memiliki dua bahasa dalam pengoperasiannya, yaitu tampilan biasa (tampilan web) dan tampilan dalam bentuk koding. Penggunaan koding (sebagaimana telah dibahas didalam modul penuntun pembuatan) dipakai dalam melakukan format pada ukuran pixel gambar dan video pembelajaran yang dimasukkan kedalam e-modul. Penggunaan koding juga diperlukan dalam membuat kuis menggunakan SIGIL, namun materi ini belum disampaikan kepada peserta pelatihan untuk menghindari kerumitan terhadap pengguna baru. Sehingga dalam penggunaannya SIGIL memerlukan pengetahuan untuk melakukan koding agar e-modul yang dihasilkan memiliki fitur yang lebih lengkap. Namun untuk menghasilkan e-modul yang lebih sederhana dapat menggunakan metode yang tercantum dalam modul pelatihan.

Pem buatan Modul Menggunakan SIGIL Bersifat up to date

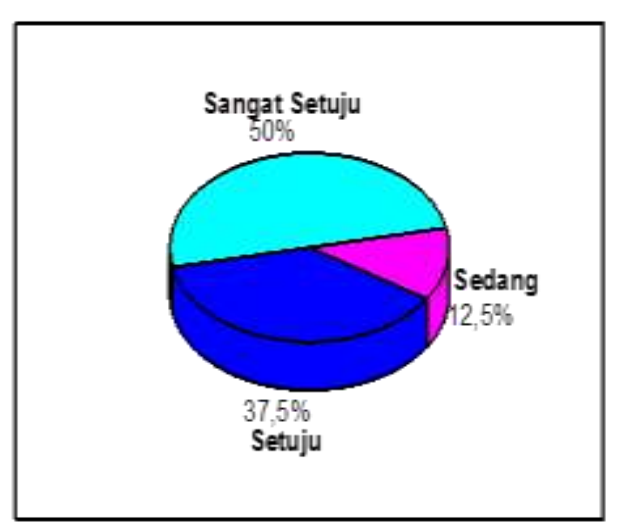

Gambar 3 Diagram kepuasan partisipan terhadap kebaruan software SIGIL dalam pembuatan e-modul

Meskipun penggunaan SIGIL dalam memproduksi e-modul tampak sedikit mengalami kendala, namun 
Volume 2, Nomor 1, Tahun 2020 Hal 265 - 281

sebanyak $50 \%$ partisipan sangat setuju dan $37,5 \%$ satuju bahwa SIGIL masih memenuhi unsur kebaruan (Gambar 3). Hasil survey ini menunjukkan bahwa istilah e-modul dan metode pembuatannya masih sangat asing di telinga para guru. Hal yang masih sangat baru ini dapat dijadikan tantangan dalam memicu inovasi guru dalam melakukan persiapan, proses, dan evaluasi dalam pembelajaran. Berdasarkan itu pula, terlihat bahwa kegiatan pengabdian kepada masyarakat yang dilakukan oleh Program Studi Pendidikan Fisika juga membawa wawasan baru bagi guru-guru MTs YAPPI Mulusan, Gunung Kidul, Yogyakarta. Hal ini juga sesuai dengan salah satu keunnikan dari Program Studi Pendidikan Fisika, yaitu memiliki kekhususan dalam pembuatan media atau alat peraga pembelajaran. Melalui pelatihan ini, guru-guru dapat memperoleh motivasi untuk membuat media ajarnya (e-modul) dalam bentuk digital yang sesuai dengan perkembangan zaman.

\section{Penilaian atas kebermanfaatan e-modul yang dihasilkan dari pelatihan}

Bagi peserta, pelatihan pembuatan e-modul ini menghasilkan e-modul pembelajaran yang dimiliki oleh setiap peserta. Evaluasi kepuasan partisipan pada e-modul yang dihasilkan selama pelatihan menunjukkan sebanyak $71,9 \%$ partisipan setuju dan $28,1 \%$ partisipan sangat setuju bahwa emodul yang dihasilkan sangat memenuhi harapan. Tidak ada peserta yang menyatakan bahwa emodul yang dihasilkan tidak bermanfaat. Dari rerata persentase tersebut terlihat bahwa e-modul yang dihasilkan selama pelatihan dapat digunakan untuk menunjang keefektifan pembelajaran. 
Tabel 2 Kepuasan partisipan terhadap e-modul yang dihasilkan dari pelatihan

\begin{tabular}{|c|c|c|c|c|c|c|}
\hline \multirow{2}{*}{ No } & \multirow{2}{*}{ Kriteria Penilaian } & \multicolumn{5}{|c|}{$\%$} \\
\hline & & TS & KS & C & $\mathbf{S}$ & SS \\
\hline 1. & $\begin{array}{l}\text { Isi e-Modul yang dihasilkan sesuai dengan } \\
\text { kebutuhan }\end{array}$ & 0 & 0 & 0 & 62,5 & 37,5 \\
\hline 2. & E-Modul yang dihasilkan User Friendly & 0 & 0 & 0 & 87,5 & 12,5 \\
\hline 3. & $\begin{array}{l}\text { Template E-Modul yang dihasilkan sangat } \\
\text { lengkap (Tujuan Pembelajaran, Materi, contoh } \\
\text { soal, latihan, evaluasi, rangkuman) }\end{array}$ & 0 & 0 & 0 & 50,0 & 50,0 \\
\hline 4. & $\begin{array}{l}\text { Pengoperasian e-Modul menggunakan Software } \\
\text { e-Reader Stabil dan Lancar }\end{array}$ & 0 & 0 & 0 & 87,5 & 12,5 \\
\hline & Rerata Persentase & 0 & 0 & 0 & 71,9 & 28,1 \\
\hline
\end{tabular}

Terdapat empat kriteria yang digunakan untuk mengukur kepuasan partisipan terhadap e-modul yang dihasilkan selama pelatihan (Tabel 2). Dari keempat kriteria tersebut menunjukkan dominan partisipanm memilih kriteria setuju, hal ini mengindikasikan terdapat sedikit keraguan dalam penggunaan emodul, rerata persentase sangat setuju yang paling kecil adalah pada kriteria 2 dan 4. Pada kriteria 2 dan 4 menunjukkan hanya $12,5 \%$ partisipan menyatakan e-modul yang dihasilkan ramah terhadap pengguna dan dapat digunakan secara stabil dan lancar, hal ini menunjukkan masih terdapat sedikit kesulitan dalam menggunakan e-modul yang dipakai. Kesulitan ini terlihat dalam pembacaaan e-modul melalui ponsel pintar atau layar desktop yang dipakai. Untuk dapat dibaca, pengguna harus menginstal software e-reader kedalam gagdet, sehingga pada awal penggunaan pengguna akan tampak sedikit lebih rumit dibandingkan jika membaca file dokumen dengan eksistensi .doc atau .docx, .pdf, dan .ppt atau .pptx.

Presentasi peserta yang setuju dalam kebermanfaatan e-modul terlihat pada kriteria ketiga, yaitu tentang kelengkapan template emodul. Dalam bentuk e-modul, bentuk media pembelajaran yang dapat dimasukkan kedalamnya tentuk akan lebih kompleks daripada modul konvensional. Dalam e-modul tentunya dalpat memasukkan gambar bergerak, gambar dengan suara, video, simulasi, animasi, dan bahkan kuis online. SIGIL juga 
Volume 2, Nomor 1, Tahun 2020 Hal 265 - 281

menyediakan pembuatan kuis dan game dalam e-modul. Pembelajaran berbasis game dapat meningkatkan keberhasilan belajar, sebagaimana ditemukan oleh Mclaren, dkk (2017) dalam pembelajaran matematika ${ }^{8}$. Kelebihan ini tentu akan membuat kualitas pembelajaran semakin tinggi karena menyediakan sumber belajar dalam bentuk yang lebih bervariasi dan lengkap.

\section{Kepuasan partisipan atas} instruktur pelatihan

Salah satu aspek yang dinilai untuk menentukan keberhasilan dari pelatihan ini adalah mengetahui kepuasan peserta terhadap intruktur pelatihan e-modul (Gambar 4). Instruktur pelatihan dalam pelatihan ini merupakan dosen program studi pendidikan fisika FKIP Universitas Kristen Indonesia.

\section{SIMPULAN}

Dari hasil angket yang dibagikan kepada partisipan kegiatan pelatiham pembuatan e-modul dalam rangka pengabdian kepada masyarakat yang diselenggarakan

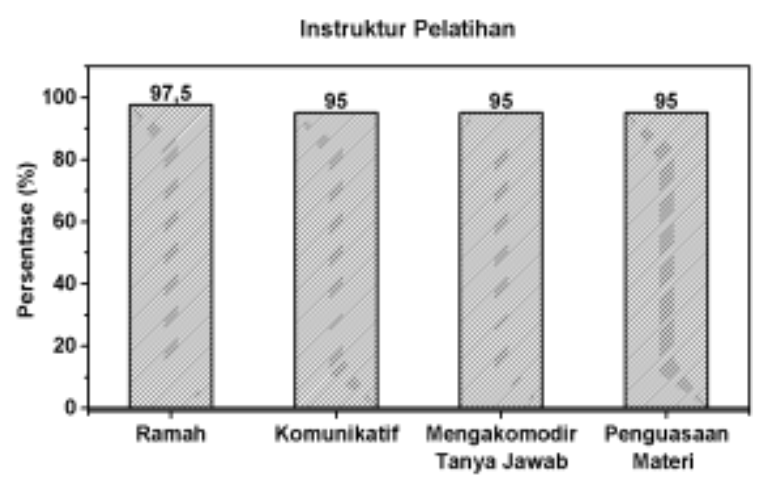

\section{Gambar 4 Diagram kepuasan partisipan terhadap instruktur pelatihan}

Dari hasil kuesioner yang dibagikan kepada partisipan dapat diketahui $97,5 \%$ menyatakan instruktur pelatihan melakukan pelayanan dengan ramah, dan masing masing 95\% terhadap kriteria penguasaan materi, kepuasan peserta dalam tanya jawab, dan komunikatif.dari hasil ini menunjukkan bahwa secara dominan, instruktur pelatihan telah melakukan pelayanan dalam pelatihan dengan baik, sehingga kepuasan peserta terhadap instruktur dapat tercapai.

oleh Program Studi Pendidikan Fisika FKIP UKI, diperoleh bahwa kegiatan pelatihan yang telah dilaksanakan relevan/sesuai dengan kebutuhan guru, bermanfaat dalam melaksanakan tugas guru di sekolah, 
Volume 2, Nomor 1, Tahun 2020 Hal 265 - 281

software SIGIL merupakan software yang memenuhi sifat kebaruan dan termasuk sederhana untuk digunakan dalam membuat e-modul, e-modul yang dihasilkan juga cukup lengkap walaupun sebagian kecil peserta masih mengalami kendala dalam pembacaan e-modul; dan peserta pelatihan sangat puas terhadap instruktur pelatihan yang dilakukan. Meskipun masih terdapat sedikit kesulitan, namun setiap partisipan dalam kegiatan telah berhasil membuat e-modul secara mandiri, dengan demikian langkah awal dalam mempersiapkan blended learning telah tercapai.

\section{UCAPAN TERIMA KASIH}

Ucapan terima kasih diberikan pada LPPM UKI dalam pendanaan kegiatan pelatihan pembuatan emodul dalam rangka pengabdian kepada masyarakat oleh Program Studi Pendidikan Fisika FKIP UKI. Ucapan terima kasih kepada dekan FKIP UKI yang telah mendukung kegiatan ini. Ucapan terima kasih juga diberikan pada MTs YAPPI Mulusan, Gunung Kidul, Yogyakarta, atas respon aktif dan kooperatif dalam pelatihan. Di akhir kata, semua peserta menyarankan agar yang akan datang lebih banyak guru yang dilibatkan.

\section{REFERENSI}

(disusun secara alfabetis menggunakan sistem American Psychologica

Hwang, G., Tu, N. \& Wang, X. Creating Interactive E-Books through Learning by Design: The Impacts of Guided PeerFeedback o $\mathrm{n}$ Students , Learning Achievements and Project Outcomes in Science Courses. Educ. Technol. Soc. 21, 184-197 (2016).

Hwang, G.-J., Lai, C.-L. \& Wang, S.Y. Seamless flipped learning: a mobile technology-enhanced flipped classroom with effective learning strategies. J. Comput. Educ. 2, 449-473 (2015).

Hsiao, C., Tiao, M. \& Chen, C. Using interactive multimedia e-Books for learning blood cell morphology in pediatric hematology. BMC Med. Educ. 1-8

doi:10.1186/s12909-016-0816- 
Volume 2, Nomor 1, Tahun 2020 Hal 265 - 281

9

Grover, A. P. E-Books as Noninteractive

Textual

Compositions: An Argument for Simplicity over Complexity in Future E-Book Formats. Publ. Res. Q. 32, 178-186 (2016).

Yalman, M. Preservice $\mathrm{t}$ eachers ' views about e-book and their levels of use of. ProcediaSocial Behav. Sci. 176, 255262 (2015).

Hwang, G. J. \& Lai, C. L. Facilitating and Bridging Out-Of-Class and In-Class Learning: An Interactive E-Book-Based Flipped Learning Approach for Math Courses. 20, 184-197 (2017).

Kozak, Greg L., and G. A. K. Printed Scholarly Books and E-book Reading Devices: A Comparative Life Cycle Assessment of Two. IEEE Int. Symp. Electron. Environ. 291296

(2003).
doi:10.1109/ISEE.2003.12080

92

Mclaren, B. M. et al. A ComputerBased Game that Promotes Mathematics Learning More than a Conventional Approach. Int. J. Game Based Learn. 7, 36-56 (2017).

Ma, M. \& Wei, C. A comparative study of children' $s$ concentration performance on picture books : age, gender, and media forms. Routledge taylor Fr. Gr. 4820, 1-16 (2016).

Vasileva-stojanovska, T., Malinovski, T., Vasileva, M., Jovevski, D. \& Trajkovik, V. Impact of Satisfaction, Personality and Learning Style on Educational Outcomes in a Blended Learning Environment Impact of satisfaction, personality and learning style on educational outcomes in a blended learning environment. Learn. Individ. Differ. 38, 127-135 (2015). 